\title{
What's in a name? Labelling effects on analysis of the role of law in health
}

\author{
Jonathan Montgomery \\ Professor of Health Care Law, University College London, London
}

This paper considers some of the labels that have been used by scholars to define and theorise our subject area and which we are now being invited to re-imagine. These include, in roughly chronological order from my working lifetime, 'Law, Ethics and Medicine', ' 'Medical Law and Ethics', 'Law and Medical Ethics', ${ }^{3}$ Medicine, Patients and the Law', ' 'Medical Law', ${ }^{5}$ 'Health Care Law', 6 Public Health Law, ${ }^{7}$ Health Law. ${ }^{8}$ These reflect the period of academic consolidation that occurred as the subject that Margot Brazier and I have elsewhere discussed as 'modern medical law' took shape in the decades since it 'emerged' in the early $1980 \mathrm{~s} .{ }^{9}$ We have argued that an historical perspective demonstrates that the way lawyers 'imagined' the subject in the last quarter of the Twentieth Century was blinkered and neglected the long history of engagement between health and law. We showed how this neglect led to 'myths' taking root that constrained the development of legal scholarship and practice. ${ }^{10}$ This is one of the reasons why it is important to consider how 'imaginaries' have shaped our perspectives and understandings. We need to do this in order to take stock of how we might best position our efforts in the future. Our earlier paper deferred consideration of the question of the best name for our field of study, but I address that issue in this piece. ${ }^{11}$

\footnotetext{
${ }^{1}$ P. Skegg, Law, Ethics and Medicine: Studies in Medical Law (Oxford: Clarendon Press, 1985).See also S Maclean \& G Maher, Medicine, Morals and the Law (Aldershot: Gower, 1983).

${ }^{2}$ I. Kennedy, Treat Me Right: Essays in Medical Law and Ethics (Oxford: OUP, 1988).

${ }^{3}$ K. Mason \& A. McCall Smith, Law and Medical Ethics (London: Butterworths, 1983).

${ }^{4}$ M. Brazier, Medicine Patients and the Law (London: Penguin, 1987)

${ }^{5}$ I Kennedy \& A. Grubb,Medical Law: Text with Materials (London: Butterworths, 1994); M. Davies, Textbook on Medical Law (London Blackstone Press, 1996), E. Jackson, Medical Law: Text, Cases and Materials (Oxford: OUP, 2006).

${ }^{6}$ J. Montgomery Health Care Law (Oxford: OUP, 1997); J. McHale, M. Fox \& J. Murphy, Health Care Law: Text and Materials (London: Sweet \& Maxwell, 1997); S. Sheldon Feminist Perspectives on Health Care Law (London: Cavendish, 1998).

7 J. Coggon, What Makes Health Public? (Cambridge: CUP, 2012); J. Coggon, K Syrett, \& A.M. Viens, Public Health Law: Ethics, Governance and Regulation (New York: Routledge, 2017).

${ }^{8}$ T. Hervey and J. McHale Health Law and the European Union (Cambridge: CUP, 2004); see also L Gostin, Global Health Law (Cambridge MA: Harvard University Press, 2014).

${ }^{9}$ A. Grubb, 'The Emergence and Rise of Medical Law and Ethics', Modern Law Review 50 (1987), 241.

${ }^{10}$ M. Brazier \& J. Montgomery, 'Whence and Whither 'Modern Medical Law', Northern Ireland Legal Quarterly 70(1) (2019), 5.

${ }^{11}$ I am very grateful to Margot Brazier for discussing these issues with me (and much more besides). My thinking owes much to her wisdom and work, but she should not be held in any way responsible for the arguments that I make here.
} 


\section{The Argument in Outline - Why and How Labels Matter}

For the purposes of this piece, I am using the terms name and label as interchangeable. To some these words hold different quite different connotations. While 'names' are chosen by those wishing to use them about their own work, 'labels' may be externally imposed so as to exclude and control people. ${ }^{12}$ I have sought in this piece to draw on the titles that people have used about their own work, arguably fairly described as a naming process. However, I go further and suggest that the terms they use link them more strongly to some of their colleagues than to others (an externally imposed identification process). I also argue that there are problematic features of work associated with those alliances (thus linking them together to receive criticism). This feels more like an adverse 'labelling' process. The tensions exposed in these processes deserve more attention than space permits here. The process of labelling so as to enable the discussing of the defects in the names used as well as their strengths is essential to the consideration of how to describe our enterprise. It cannot escape the risk of negative connotations and this must be acknowledged. Nevertheless, even stigmatising labels can be 'reappropriated' to assert identities. ${ }^{13}$ Nor should we assume that a contested label is always an external imposition - the naming/labelling process may be more a battleground for the authority to speak, as we have seen in the USA in relation to the field of bioethics. ${ }^{14}$ In the UK, some are proud to claim the name of bioethicist but others are embarrassed to adopt the label. ${ }^{15} \mathrm{My}$ aim in this piece to be as objective as I can in discussing these issues, but as a participant in the processes that I am describing it is probable that I will have 'named' work with which I am sympathetic and 'labelled' that about which I have doubts. I have tried to use the terms 'name' and 'label' interchangeably in order to leave that judgment open to readers.

I draw on ideas from semiotics and social theory. First, that names/labels do not merely correspond to objects but create rich meanings through connotations. ${ }^{16}$ Second, that processes of naming/labelling contain implicit judgements of similarity/difference and inclusion/exclusion, which in turn have powerful effects on the way in which people understand themselves and others and their places in the organisation of society. ${ }^{17}$ Third, that these processes are socially rooted, and constitute an exercise of power that necessarily involves a degree of 'symbolic violence' in which domination is concealed within our language and practices. ${ }^{18} \mathrm{I}$ take it that these three insights encourage us to consider, first, the richness of meanings that go with the names/labels that we use. Second, that we should examine how those names/labels influence our perception of our subject, and reflect on the possibilities and limitations that different naming options bring. Third, we should

\footnotetext{
12 See e.g. S. Cohen, Folk Devils and Moral Panics: the creation of the Mods and Rockers (Oxford: Martin Robinson $2^{\text {nd }}$ ed 1980).

${ }^{13}$ A. Galinsky, K. Hugenberg, C. Groom, G. \& Bodenhausen, 'The reappropriation of stigmatizing labels: Implications for social identity' in J. Polzer, M. Neale, \& E. Mannix (Eds.), Identity issues in groups. (Greenwich, CT: Elsevier Science Press, 2003).

${ }^{14} \mathrm{~J}$. Evans, The history and future of bioethics: A sociological view (Oxford: Oxford University Press, 2012); L. Eckenwiler \& F. Cohn (Eds.), The ethics of bioethics: Mapping the moral landscape (Baltimore: Johns Hopkins University Press, 2007).

${ }^{15}$ N. Priaulx, 'The troubled identity of the bioethicist. Health Care Analysis, 21 (2013), 6.

${ }^{16}$ See e.g. R. Barthes, 'The Rhetoric of the Image' in Image-Music-Text (London: Fontana, 1977).

17 See e.g. H. Becker, Outsiders: Studies in the Sociology of Deviance (New York: Free Press, new edition 1977, original 1963).

${ }^{18}$ See e.g. P. Bordieu, Reproduction: In Education, Society and Culture (London: Sage, 1977) and his study of French academia, P. Bordieu, Homo Academicus (Cambridge: Polity, 1988). For discussion, J. Thompson, 'Symbolic Violence: Language and power in the writings of Pierre Bordieu' in his Studies in the Theory of Ideology (Cambridge: Polity Press, 1984), 42.
} 
be attuned to the way in which names/labels are linked with social power so as to be able to discuss whether that power is exercised legitimately.

I begin by reflecting on the associative meanings of some of the recent names used by scholars for our subject. Whether consciously or not, such labelling makes implicit assumptions about the nature of our work, which in turn colour our analysis. Some of these variations may seem quite subtle, but considering them helps us to understand the complexities of the choices before us, illustrates the options that are available to carry forward into our future scholarship, and enables some preliminary observations about what is at stake in the naming process.

We should be alert, however, to a less generous perspective on labelling activity that relates it to the status 'games' that are being played out (again not necessarily consciously, nor wholly avoidably). I therefore retell some of this history in terms of people, places and activities to show how labels function as the currency for transactions in academic life. ${ }^{19} \mathrm{I}$ do this to acknowledge that there might be some unpalatable undercurrents to the way we stake our claims to name the field. However, we should not be dissuaded from harnessing the positive potential of 'naming'. Labels serve to identify and organize the materials so that they can be studied. Without this, we would be overwhelmed and lost in a conceptual world 'without form and void'.$^{20}$ The creative processes of dividing materials, grouping like with like, and separating them from others are what makes study and understanding possible. This can be primarily a passive descriptive exercise, in which labels are to be judged in terms of their ability to explain how the law has developed, how it 'works'. There is more, however, to the power of naming. It is also an exercise of dominion over the things that are named. ${ }^{21}$ I therefore, turn to consider the normative value of names - how they help us to decide what to do for the future. Here we need to be alert to the need to justify this exercise of power if we are to avoid falling into the pitfalls.

I therefore discuss the framing effects of the labels that we choose; looking more closely at medicine, health care, and health as organising categories. This illustrates the way in which the name that is adopted influences the content of the subject, the way it is presented, and also the normative priorities that those working within the paradigm tend to adopt. This is not a matter of logic but practice. It is important not to overplay the claim that is being made. It is not that these are different subjects, so much as different angles from which they are examined. There is considerable overlap between these approaches. Nevertheless, a different sightline will tend to bring some issues further into the light than others. None of the approaches offers perfect vision and the views may be obstructed or obscured in different ways. I hope that this account will show that our choices of labels must remain open and should be seen as tentative in the way that scientific theories are supposed always to be open to challenge, testing and falsification. ${ }^{22}$

Finally, I suggest that we need to be alert to the possibility that the dynamic of our area of law, whatever it is best called, may be driven by wider political or social currents for which the legal context is incidental rather than central. I will discuss this briefly using the metaphor of names as

\footnotetext{
${ }^{19}$ A similar point could be made about professional activities too. For some tentative observations on the way in which the recognition of particular lawyers as expert in a field has an impact of the content of the law, see J. Montgomery, C. Jones \& H. Biggs, 'Hidden Law-making in the Province of Medical Jurisprudence' Modern Law Review 77(3) (2014), 343, 366-9.

${ }^{20}$ Genesis 1:2.

${ }^{21}$ Thus, in the second of the two creation stories recorded in the first books of Genesis, God divides and orders the world, but then gives Adam the power to name the living creatures (Genesis 2:19-20).

${ }^{22}$ See T. Lewens, The Meaning of Science (London: Pelican, 2015) for an introduction to the philosophy of scientific method, especially the chapter 'How Science Works', 11-43.
} 
icons - symbols of cultural significance that help shape our understanding of common values. ${ }^{23}$ This is significant for our project because it concerns the connections between legal categories and other ways of understanding society rather than the demarcation of one legal field from another. It may be that when we come to consider the merits of new names that these type of connections prove a significant factor in the choices we will make. It may also be that we sometimes need to put aside the question of labelling our own subject in order to engage with issues of public importance. For these various reasons, labelling questions may be subsidiary issues.

I am not arguing that old and failed paradigms are superseded by new and more comprehensive ones, as in a Kuhnian revolution. ${ }^{24}$ However, I am using paradigm in the sense that Kuhn adapted it. He argued that classic works in science were paradigms (literally exemplars) because they 'served to define the legitimate problems and methods of a research field' 25 and 'provide models from which spring particular coherent traditions of scientific research. ${ }^{26}$ In a postscript to the original edition of his book, Kuhn reflected how a scholarly community's commitment to a paradigm works partly through a shared sense of permissible analogies and metaphors and also a shared sense of the values to guide judgments (e.g. that good scientific theories 'should be simple, self-consistent, and plausible'). ${ }^{27}$ I suggest that the names that we adopt invoke paradigms in this sense, framing our expectations, although also sometimes leaving us dissatisfied with their 'fit'. Here, I draw on Kuhn's idea of 'anomalies' - situations where observational data have 'somehow violated the paradigminduced expectations' of researchers ${ }^{28}$ - and also his observations about how reluctant we can be to let go of those expectations. He discusses how allegiance to paradigms leads to restriction of vision and resistance to paradigm change, and that at times the dissonance reaches such a pitch that a crisis occurs and a paradigm breaks. I think all of the models of our subject display such anomalous elements. However, it does not follow either that they need replacing (perhaps we need merely to be more aware of their limitations) nor that they are not useful. Indeed, Kuhn notes that we need paradigms to direct our attention and it is this that helps us become aware of the fact that the expectations fostered by our paradigms have in fact been confounded by our research (that is an anomaly has been identified). ${ }^{29}$

I am not arguing for a new paradigm, ${ }^{30}$ but I am suggesting that the choices we make about the naming of our field of study have costs and risks as well as benefits. We need to make those choices with our eyes open and with as comprehensive as possible an appreciation of the differences that the available labels offer. Elsewhere in this collection, Margot Brazier discusses elements of the journey that she and other pioneers took and stresses that much of this was accidental rather than carefully planned. While, it is important to acknowledge this, we have the opportunity now to take responsibility for making more informed choices about the paths we want to tread in the future. Note, this is paths in the plural. My conclusion will not argue for a single new name but reflects on

\footnotetext{
${ }^{23}$ My thinking here has been influenced by Rowan Williams' discussion in Lost Icons (London: T \& T Clark, 2000) and D. Morgan \& R. Lee, 'Regulating the Risk Society; stigmata cases, scientific citizenship and biomedical diplomacy' Sydney Law Review (2001), 297.

24 T Kuhn, The Structure of Scientific Revolutions (Chicago: University of Chicago Press: $4^{\text {th }}, 50^{\text {th }}$ Anniversary, ed 2012).

${ }^{25}$ Kuhn, 10.

${ }^{26}$ Kuhn, 11.

${ }^{27}$ Kuhn, 183-4.

${ }^{28}$ Kuhn, 53.

${ }^{29}$ Kuhn, 64-5.

30 I once thought that such a 'paradigm shift' might be underway, see J. Montgomery 'Time for a Paradigm Shift? Medical Law in Transition' Current Legal Problems 53 (2000), 363, but I currently think the problem is more complex and that change over time, whether evolutionary or revolutionary, is not the key issue.
} 
the most salient features of the tasks ahead that I think need to be taken into account as we consider how to describe what we are working on. This raises the possibility that there is no single satisfactory conception of the field and that a plurality of labels may be inevitable in the foreseeable future. Thus, Kuhn's framework for explaining how paradigms is very helpful, but it does not follow that we should expect a paradigm shift from one to another. Instead, it alerts us to possibility that the material we are seeking to explain may not neatly fit the paradigm we are using to frame our understanding.

\section{A Brief History of our Labels}

I began with a list of names that were chosen by some of the leading scholars in our field for their representation of what is being considered. I don't think that there will be much disagreement that at least these works should be considered as part of the canon, ${ }^{31}$ although many others might also be contenders. ${ }^{32}$ I offer now a brief sketch of the nuances of these labels. I am not claiming to describe the intentions of those who used them (on which, see the next section) but to draw attention to the assumptions that labels can import and the associative meanings that they suggest. Three dimensions seem significant. First, the academic disciplines that labels suggest have jurisdiction over the area of study..$^{33}$ Second the delineation of a body of material that should be our focus. I shall reference to this as a reification process, whereby an idea becomes a 'thing'. In our area, this can be conceived quite literally in the way in which educational works collect together legal documents for study. Thus, some of the leading student books in our field take the form of 'text and materials' rather than a traditional textbook. From a longer view, the 'textbook' is a more modern format than the collection of annotated materials which is a far more ancient tradition. ${ }^{34}$ Third, a concern with social actors, individuals and organisations, and the way they behave and interact. This can be considered as a model of 'law and...' in which the task is understood to bring various strands of legal doctrine to apply to a particular social context, but no claim is necessarily made to this being a discrete area of law with its own doctrinal identify. I illustrate these groupings by reference to some well-known texts.

In the first category, a concern with 'Law, Ethics and Medicine' might be said to describe the phenomenon of three academic (or academic/professional) disciplines inhabiting a single space. There is no obvious priority ascribed. ${ }^{35}$ However, we might consider that it suggests that the activities of doctors are being subjected to legal regulation, which in turn is appraised by consideration of how well the legal principles meet the requirements of ethical analysis. If this is the case, then there is an implicit hierarchy of disciplines in which ethics is supreme, with law a tool at its service and medicine the subject of its work. This seems to be the approach adopted by scholars

\footnotetext{
${ }^{31}$ On the idea of a canon, and the difference between an assertion, such as I make here, that 'at least' these writers are authoritative and the much more challenging exclusive claim that 'at most' (only) these writers are to be seen as part of the canon, see J Barton, A History of the Bible: the Book and Its Faiths (London: Allen Lane, 2019) especially Chapter 9, 'From Books to Scripture'. The 'at least'/'at most' distinction is explained at 223-4.

${ }^{32}$ We discuss some of these in 'Whence and Whither', 16-18.

${ }^{33}$ On this, see K Veitch, The Jurisdiction of Medical Law (Aldershot: Ashgate, 2007).

${ }^{34}$ See 'Whence and Whither', 14-15; W. Twining, Blackstone's Tower: the English Law School (London: Sweet \& Maxwell, 1994), chs 5 \& 6.

${ }^{35}$ The order in which the disciplines are listed can vary, as in M. Freeman (ed) Medicine, Ethics and the Law (London: Stevens, 1988).
} 
such as John Keown, whose collected essays are entitled The Law and Ethics of Medicine. ${ }^{36}$ Or perhaps, we are seeking to identify the overlaps between the disciplines, and so are examining those aspects of medicine that raise legal questions of ethical significance. Peter Skegg's preface to his Law, Ethics and Medicine: Studies in Medical Law describes his project in such terms. He is concerned with the 'legal aspects of some issues that arise in medical practice'. Andrew Grubb criticised the work for staying too close to 'conventional' "'black letter" law' and neglecting areas of ethical controversy, but he acknowledged that these were (in the early 1980s) areas of limited legal activity - areas 'largely as yet a matter of ethical debate but an area in which lawyers do, and in the future will need to, have their say'. ${ }^{37}$

In contrast, some of our labels serve to prioritise ways of conceptualising the object of our study. These share a tendency to reify it as a body of ideas that can be identified, examined and critiqued. This in turn creates expectations of some way of defining limits (what is included), and some degree of coherence (allowing for an internal critique - whether the subject is consistent, or 'true' to itself). Once identified, this corpus of law can also be appraised from an external critical perspective. In this category, I would place the approach of 'Medical Law and Ethics'. This was adopted by Sir lan Kennedy, knighted for services to Bioethics and to Medical Law in 2002, ${ }^{38}$ as the subtitle to his influential collection of essays Treat Me Right. In this naming process, 'Medical Law' has been here reified as 'a thing'; an object of study or a corpus of law. ${ }^{39}$ Medicine itself has lost its place in the process and as a result, there is no necessary connection between the discipline of medical law and the practical context of medicine (or health care). In Kennedy's model, which shaped the approach that many others took, the key linkage for the study of medical law is with ethics. Note that this is not medical ethics, but a more general conception of philosophical ethics, and in particular the tradition of bioethics that was taking root in the USA. ${ }^{40}$ It brings an implicit claim that medical law is to be judged against standards drawn up outside of law or of medicine. The label taken by Ken Mason and Alexander McCall Smith of 'Law and Medical Ethics' can be said to make some similar assumptions about the way a label should work but providing a different perspective by reifying medical ethics and tagging on law as the disciplinary perspective that is being used to understand it. There might therefore be sister studies to books in this vein such as 'sociology and medical ethics', just as there might be supplementary volumes on 'medical law and politics'. ${ }^{41}$ In Jose Miola's iteration of this paradigm, both medical law and medical ethics get reified as objects for study, with

\footnotetext{
${ }^{36} \mathrm{~J}$ Keown, The Law and Ethics of Medicine: Essays on the Inviolability of Human Life (Oxford: OUP, 2012)

37 Grubb, 'The Emergence and Rise', at 243.

${ }^{38}$ London Gazette 28 December 2001, https://www.thegazette.co.uk/London/issue/56430/supplement/1 (accessed 9 August 2019).

${ }^{39}$ Kennedy used the phrase 'corpus of law' in Treat Me Right, 175. I note that Skegg's book also uses 'medical law'; the categorisation offered here is indicative and aimed to illuminate the way labelling operates rather than suggesting definitively different categories.

${ }^{40}$ D. Wilson \& R. Chadwick, 'The Emergence and Development of Bioethics in the UK' Medical Law Review 26 (2018), 183. D. Wilson, 'Who's for bioethics?' Ian Kennedy, oversight and accountability in the 1980s', in his The Making of British Bioethics (Manchester: Manchester University Press, 2014). See also an earlier version, D Wilson, "Who Guards the Guardians? Ian Kennedy, Bioethics and the "Ideology of Accountability" in British Medicine' Social History of Medicine 25(1) (2011), 193. On bioethics in the USA, see A. Jonsen, The birth of bioethics (New York: OUP, 2003). D. Rothman, Strangers at the bedside: A history of how law and bioethics transformed medical decision making (New York: Basic Books, 1991), and Evans, The history and future of bioethics. In the UK, Raanan Gillon's book Philosophical Medical Ethics (Chichester: John Wiley, 1986) was highly influential in introducing US bioethical thinking.

${ }^{41}$ These sorts of reflections exist in relation to bioethics; see e.g. M. Sheehan \& M. Dunn, 'On the nature and sociology of bioethics' Health Care Analysis 21 (2013), 21 54. D. Wilson, 'What can history do for bioethics?' Bioethics 27(4) (2013), 215, A Petersen, The Politics of Bioethics (London: Routledge, 2011)
}

6 | P a g e 
medical ethics conceptualised as aspiring to be like law, and comprised of sub-legal rules and documents. ${ }^{42}$

Finally, the organising feature for our studies might be the people and institutions that are engaged with social and political processes. Thus, Margaret Brazier's 'Medicine, Patients and the Law' can be said to be named for the protagonists in the drama. ${ }^{43}$ It allows for the social practices to determine the scope of study - with the task of academics to ensure that an account can be given of the legal issues that arise within those activities and how the law anticipates that they should be resolved. Thus, the original aim of my textbook 'Health Care Law' was to provide 'a comprehensive text explaining the law that governs the delivery of health care'.$^{44}$ The contents were initially determined by what my experience of speaking with health professionals showed me they wanted or needed to know. I sought to define a subject from that. Although I argued that it might draw from international legal obligations to address health concerns this was a superficial attempt to provide a plausible legal account of the boundaries of the subject. ${ }^{45}$ This perspective rooted the subject in a set of practices that was specifically concerned with the UK context of national health services. A broader approach to shaping law around the practice of health care institutions might need to recognise that this system of socialised medicine is unusual and an account of the subject based upon it may not be generalizable to other jurisdictions. One of the attractions of 'health law' as a label is that it can better accommodate this variety and address the shape of regulation of health services without being closely associated with one type of health system. ${ }^{46}$

Some labels might relate to particular activities within the broad umbrella of health services, particularly where they seem to draw on areas of law that are discrete from the mainstream of health provision. The relative separation of scholarly activity on 'mental health law' would be an illustration of this, with its focus on legislation that has little impact on non-specialist areas of health delivery (in contrast to 'mental capacity law' which is significant for everyone). The place of some areas is uncertain and 'public health law' might deserves a separate 'law and...' label as it is often institutionally separate from health services (for example sometimes sitting in local government or environmental health organisations rather the NHS) and draws on norms that seem independent of the traditional medical ethics paradigms. ${ }^{47} \mathrm{~A}$ final aspect of such 'activity-based approaches concerns the audiences to whom our work is addressed. Writing for practitioners especially health professionals and managers, might not score well in the Research Excellence Framework. However, it may represent a vital task for those legal scholars who see their work as the application of law to important social practices and services.

If the organising feature of our discipline is to be the people, practices, and institutions, then there is no necessary internal coherence or consistency to the law that we are studying. Connections may be sought not internally (within our area of law), but externally (with the categories of law that are applied to these other practices - such as public law, criminal law, tort law). Where such external

\footnotetext{
42 J. Miola, Medical Ethics and Medical Law: A symbiotic relationship (Oxford: Hart, 2007).

${ }^{43}$ See also C. Dyer (ed), Doctors, Patients and the Law (Oxford: Blackwells, 1992), J. Leahy Taylor, The Doctor and the Law (London: Pitman Medical, 1971).

${ }^{44}$ Montgomery, Health Care Law, preface.

45 There is now a considerable literature on this, see e.g. J. Tobin The Right to Health in International Law (Oxford: OUP, 2011); T. Murphy, Health and Human Rights (Oxford: Hart, 2013).

${ }^{46}$ Compare T. Hervey \& J. McHale, European Union Health Law: Themes and Implications (Cambridge: CUP, 2015) with I. Cohen, A. Hoffman \& W. Sage (eds) Oxford Handbook of US Health Law (New York: OUP, 2017). ${ }^{47}$ See Coggon, What Makes Health Public?; A Dawson, 'Resetting the parameters: Public health as the foundation for public health ethics' In: Dawson, A (ed) Public Health Ethics: Key concepts and issues in policy and practice (Cambridge: CUP, 2011).
} 
consistency is sought, we critique our given subject area by asking if it distorts basic principles drawn from elsewhere. An example of this can be seen in discussion of medical law as rooted in human rights discourse. ${ }^{48}$ This has not always been drawn from detailed analysis of human rights law, nor acknowledged debates about the appropriateness of imposing of partisan moral views in a pluralist democracy..$^{49}$ When articulated more explicitly, the connections with human rights were sometimes seen as more programmatic and political than philosophical. ${ }^{50}$ This reminds us that we need to consider the possibilities that labels are bound up with socio-political struggles for power. Thus, 'Medical Law' has been accused of being little more than and excuse for legal control over medicine and a case needs to be made that patients actually gain from a transfer of dominance from doctors to lawyers. ${ }^{51}$

We need also to consider the differences between descriptive and normative aspects of the question of naming our subject or discipline. Thus, the idea of 'Public Health Law' might be more than the law governing the work of public health officials. It may import an expectation of the instrumental use of the law to promote public health. Is health law to be measured by whether it promotes health, or does it concern the regulation of health markets without such an instrumental purpose (possibly measured by its promotion of their efficiency)? Should 'Health Care Law' have improving the quality of health services as an aim, or is this for health policy? Can the acceptability of substantive rules within medical or health care law be assessed without making judgments about their moral content? This interplay between a concern to make things better by studying the law and being clear about what the legal expectations are has been a source of some confusion in the history of the academic work with which we are concerned. Scholars working in this area often believe they are making a positive difference, but it is possible that we may be deluded in this.

\section{Labels as Power: an Alternative History}

Labels function as the currency of power struggles; of humans to establish order over the chaotic world in which they live (including, in order to write a student textbook), of one scholar against others for supremacy, of one profession or discipline against another. This can be considered as an instrumental aspect of the debate about what to call our subject area, and it invites us take care to acknowledge the functions, aims and objectives that are served by the use of any chosen definitional category in order to consider what our response to it might be. We might recast the list of changing labels that has just been described as representing people rather than things. Thus, the same list could denote the authors: Skegg, Kennedy (with Grubb and followed by Jackson), Mason-McCall Smith (taken forward by Laurie), Brazier (now with Cave), Montgomery (taken up by McHale and Fox), Gostin-Coggon, Hervey-McHale. These individuals are all authors who have made their mark on the history of scholarship by, amongst other things, carving out a niche that has staked its claim through being labelled differently to their colleagues' and competitors' work.

\footnotetext{
${ }^{48}$ S. Lee, 'Judges, human rights and the sources of medical law' in P. Byrne (ed) Health, Rights and resources (King Edwards Hospital Fund for London, 1987), esp 36-7. See also E Wicks, Human Rights and Healthcare (Oxford: Hart, 2007).

49 J. Montgomery, 'The Legitimacy of Medical Law' in S. Maclean (ed), First Do No Harm: Law Ethics and Medicine (Aldershot: Ashgate, 2006), 1. See also Jean McHale's paper in this special issue.

${ }^{50}$ S. Maclean Old Law, New Medicine: Medical Ethics and Human Rights (London Pandora 1999)

${ }^{51}$ R. A. Hope, 'The birth of medical law' Oxford Journal of Legal Studies 11 (1991), 247.
} 
We should not underestimate the importance of their individual careers in influencing the naming process. Ian Kennedy's work would probably have been very different had he not spent time studying, researching and teaching in the USA. ${ }^{52}$ Andrew Grubb came into medical law because he was asked to teach a course. ${ }^{53}$ Ernest Owusu-Dapaa has suggested that my own work is largely a reaction against perceived weaknesses in lan Kennedy's approach, offering this as one of two main reasons for my entering the field. ${ }^{54}$ This raises the uncomfortable possibility that the emergence of health care law as a label might be little more than an angry young man's reaction to authority. Nor should we forget that the inclinations of individual scholars about how to do their work will inevitably influence their conclusions, as a study of different approaches to analysis of the Sidaway judgment has demonstrated. ${ }^{55}$ We should acknowledge these accidents of history and be alert to their impacts. However, we should also put aside the temptation to explain everything in accidental terms and to suggest that we have to accept the names that have been adopted. The key point is that these contexts require us to consider the place of labels as currency in the descriptive and normative projects in which they were are put to use. If the projects change, then the labels may need to as well.

Projects can be institutional as well as individual. The process of naming creates order, it makes it possible to analyse an otherwise messy and disorganised mass of data and examples. We could not teach a course, or bundle of courses to create a degree programme, without choosing names. ${ }^{56} \mathrm{We}$ cannot apply for grants without knowing where to apply, defining our projects and showing how they relate to past work and future impact. We cannot establish a centre without giving it a name, preferably with a snappy acronym. Thus, Ernest Owusu Dapaa's study of the emergence of health care law notes centres in Medical Law and Ethics (CMLE, Kings College London), Social Ethics and Policy (CSEP, Manchester), Health Ethics and Law (HEAL UoS, Southampton), Bioethics and Medical Law (Lancaster), Health Law, Science and Policy (CHSLP, Birmingham), Ethics, Law and Life Sciences (CELLS Durham) ${ }^{57}$ Even this list is not complete and notable additions should include the Sheffield Institute of Biotechnological Law and Ethics (SIBLE) and the Institute of Medicine, Law and Bioethics (IMLAB, Liverpool, Manchester, Keele, Lancaster and Central Lancashire). The naming of centres requires something to be presented as new and distinctive, with a differentiated mission. It is therefore no surprise that, unlike the naming of textbooks, the labelling of centres shows little overlap. Each asserts an individual identity rather than alliance with others. But these names may also be pragmatic and reflect opportunism, and the marketability of slogans (perhaps these days, hashtags), as much as intellectual coherence.

\footnotetext{
52 D. Wilson, 'Who's for bioethics?', D. Wilson, 'Who Guards the Guardians?'.

${ }^{53}$ E. Owusu-Dapaa (2016) An Inquiry into the Emergence of Health Care Law in England and Wales as a Distinct Body of Law - What Lessons Can be Drawn From this in Relation to Ghana? University of Lancaster PhD Thesis. This includes interviews with a number of early scholars.

${ }^{54} \mathrm{E}$ Owusu-Dapaa, 228, cites my 'dissatisfaction with how the leading light on the academic status of $\mathrm{HCL}$, lan Kennedy, had presented the subject to the public and legal academy in the 1980s. This particular motivation has been consistently evident in the way Montgomery has developed his vision for the field of HCL through his scholarship and public service roles. For example, he has on various occasions and in different contexts criticised Kennedy's type of HCL, which proceeds from a prior postulation about the doctor-patient relationship and rather contends that the proper emphasis of the subject ought to be on ascertaining and shaping the actual norms of the healthcare system that dictate the realities of HCL.'

55 J. Montgomery, 'The Compleat Lawyer - Medical Law as Practical Reasoning: Doctrine, Empiricism, and Engagement' Medical Law Review 20 (2012), 9.

${ }^{56}$ R. Nwabueze, 'Health care law curriculum and scholarship in Canada, USA and England: lessons for Nigeria' Law Teacher 44(1) (2010), 32.

${ }^{57}$ E Owusu-Dapaa, 'The Historical Development of Health Care Law and Bioethics in England and Wales: A symbiotic relationship' Medicine and Law 33(1) (2014), 22.
} 
Naming creates both opportunities and boundaries. It includes things and helps to bring them into the centre of consideration - we can therefore use the naming process to draw attention to those things that had been neglected. However, naming also excludes some things and downgrades some of those that are within the remit by making them seem peripheral or subordinate. This can make it difficult, even almost impossible, to discuss them. I therefore turn to this aspect of naming.

\title{
4. Labels as Interpretive Frames
}

The labels that we use to describe things have important framing effects. I adopted 'Health Care Law' in order to bring forward the role of the law in promoting good health, to raise the profile of the legal position of professionals other than doctors, and to better capture the way in which the National Health Service was regulated. I thought this remedied some blind spots in the 'medical law and ethics' paradigm. The way in which I organized the material made different areas of law the primary consideration. This can be seen quickly from the contents pages of three textbooks that adopt these labels (Table 1 ).

\section{Table 1: Contents of three illustrative student works}

\begin{abstract}
I Kennedy \& A Grubb Medical Law ${ }^{58}$ : PART I The provision of medical care; Regulation of health professionals, discipline and complaints; PART II.; Medical Law: The General Part; Medical negligence; Consent; Consent by others; Medical records; Confidentiality; PART IIIIV.; Medical Law In Action: A The Beginning of Life; Contraception and sterilisation; Medically assisted reproduction; Abortion; B During Life; Actions for damages by children and parents arising from occurrences before birth; Products liability; Research; Donation and transplant of human tissue and fluids; C The Ending of Life; The end(ing) of life: the competent patient; The end(ing) of life: the incompetent patient; Death and dead bodies
\end{abstract}

J Montgomery, Health Care Law: ${ }^{59}$ The Scope and Sources of Health Care Law; Part I: Health and the Law; Public Health Law; Rights to National Health Service Care; The Structure of the NHS; National Health Service Complaints; Part II: Health Care Practice and the Law; Professional Regulation; Malpractice Litigation I: The Law; Malpractice Litigation II: In Practice; Medicines and the Law; Part III: The Position of the Patient; Consent to Treatment; Confidentiality and Data Protection; Care for Children; Mental Health; Research; Part IV: Health Care Law and Ethics; Abortion; Fertility; Maternity Care; Selective Treatment of the Newborn; Transplantation; Terminal Care and Euthanasia; Regulating Health Care Ethics.

T Hervey \& J McHale, Health Law and the European Union: ${ }^{60}$ Introduction; Historical, legal and institutional contexts; Community competence in the field of health; Access to health care services; Data protection and health information policy; Regulation of health care

\footnotetext{
58 I. Kennedy \& A. Grubb Medical Law (London: Butterworths, $3^{\text {rd }}$ Ed 2000).

59 J. Montgomery, Health Care Law (Oxford: OUP, $\left.2^{\text {nd }} E d, 2003\right)$.

${ }^{60}$ T Hervey \& J McHale, Health Law and the European Union (Cambridge: CUP, 2004). See also T Hervey \& J McHale, European Union Health Law: Themes and Implications (Cambridge: CUP, 2015), especially the discussion of labels in chapter 2.
} 
professionals; The regulation of clinical research; Regulating pharmaceuticals: risk, choice and compensation; Public Health law; Conclusions and future prospects.

Thus, 'Medical Law' starts from medical care and the regulation of the professionals who deliver it. 'Health Care Law' opens with the duties of health ministers and institutional structures of the NHS that are aimed to meet them. 'Health Law' is organised around the regulation of health markets. ${ }^{61}$ The differences should not be exaggerated. An examination of the legal materials that are covered (cases and statutes) shows considerable overlap between the medical and health care law texts. It could be suggested that these are different presentations of a single dataset. The European focus of 'Health Law' necessarily leads to a different range of materials. However, it also provides a different emphasis, in which the structure of market regulation is the main concern and few of the problems in medical ethics that concern the other two texts get attention. It is possible to draw out some observations even from this high level comparison that will be important in selecting labels as we reimagine our subject are for the future.

First, in the domain of content, our re-imagination needs to grapple with some examples of areas of law that look very different depending on the focus selected. A good example would be the law relating to medicines. This might be seen as central to health law with its focus on the conditions of market regulation and the availability of products to care providers. However, it is peripheral to medical and health care law where the interaction between patients and care providers attracts the main attention. Is our concern in relation to the regulation of medicines primarily with safety and efficacy as conditions of market access (health law), the responsibilities of prescribers (health care law) or the rights of patients to know about side effects and alternative treatments (medical law and ethics)? The first of these relates to products rather than individual uses and makes the most important legal actors the companies that develop medicines. It will be centrally concerned with the requirements for making medicines available. The second examines the regulation of professional judgment and is concerned with decisions made about whether to select and offer products that are available in the market to specific patients. The third engages with the decisions to be made by patients and how to ensure that they are properly informed. The perspective to be taken will shape the content that is deemed appropriate as a description of the legal framework in question.

We can see differences of emphasis in relation to more normative approaches, in which the legal analysis aims to provide a context for evaluation. Here, we might take abortion as a case study: Medical Law might typically place ethical issues at the centre (When can a doctor terminate a pregnancy? What rights of conscientious objection should be provided?). ${ }^{62}$ Health Care Law might focus on the nature and scope of women's rights to services, and begin by examining the

\footnotetext{
${ }^{61}$ Some argue for a definition of health law drawn from human rights, but this would very different from the version discussed here. Human rights do not register in the USA context. Even L. Gostin, Global Health Law (Cambridge, MA: Harvard University Press, 2014) devotes only one of the fourteen chapters to human rights, concentrating instead on international law more broadly. Hervey and McHale European Union Health Law (2015), 40-53, discuss how human rights are subsumed into social solidarity in the EU. See also G. Bache, M. Flear \& T. Hervey, 'The Defining Features or the European Union's Approach to Regulating New Health Technologies', in M.L. Flear, A.M Farrell, T.K. Hervey, et al., eds., European Law and New Health Technologies (Oxford: Oxford University Press, 2013), 7-45, showing that human rights are marginal considerations. I return briefly to this issue in the conclusion.

62 The use of the term 'ethics' is not a necessary consequence of the label, but it does reflect how the literature from this paradigm has tended to approach it. It is possible to describe the questions of what the doctor may and must do as practical issues, but in practice this is generally understood tp raise ethical questions.
} 
entitlements under the NHS Acts and human rights law. ${ }^{63}$ This is perhaps a consequence of the tendency of health care law to be located in public law rather than accept the private law paradigm of medical law. ${ }^{64}$ Health Law might concentrate on the conditions that govern market access for abortion providers and start from the work of the Care Quality Commission. ${ }^{65}$ Public Health Law might make the central question how we ensure abortions are safe, rather than concentrate on the question of legality (given that legality does not seem to affect the incidence of terminations). ${ }^{66}$ Each of these is a legitimate approach, but they frame the problems differently. Through that framing, some issues become more difficult to discuss and some solutions become more likely to fit. Thus, medical law is likely to place greater weight on the importance of individual rights of conscience than the other approaches mentioned in this paragraph. Health Care Law's concern with the obligations of the system to provide services makes it more likely to see conscientious objection as a constraint on those primary duties that must be balanced against each other ${ }^{67}$ Health Law will tend to suppress the unusual features of abortion in favour of the general approach to regulating health providers. Public health law tends to assume the prevalence of abortion and seek to mitigate its harmful aspects rather than stop it happening.

Scholars are sometimes quite explicit about the assumptions behind their work, both descriptive and normative, but more rarely note the framing effects that follow from those assumptions. This can be seen in relation to their search for underlying unities, which constitutes another important domain that needs consideration in the naming of subjects. Kennedy and Grubb explain that 'Medical Law's concern is with 'common issues which permeate all the problems which arise: respect for autonomy, consent, truth-telling, confidentiality, respect for personhood and persons, respect for dignity, and respect for justice. ${ }^{68}$ Here, the search for unity thus lies in conceptual categories and basis of critique is broadly philosophical - are those values properly met?

Health Care Law's concern with the implicit value structures of the health professions and the NHS leads to an interest in how social power might be legitimated and an understanding of the issues as generally arising in a public law context (less obvious in the medical law paradigm). In Health Care Law, the underlying unity lies in habitual acceptance of these norms, with a working assumption of their integration into the law. Here, one might judge the effectiveness of the law by considering whether law and other norms are complementary and whether services are improved by their interaction.

These service norms may be the very thing that is called in question by the way the enterprise is framed. Thus, Gostin has described 'Public Health Law' as being the 'study of the legal powers and duties of the state... to ensure the conditions for people to be healthy (to identify, prevent, and

\footnotetext{
${ }^{63}$ See e.g. R. Scott, 'Risks, Reasons and Rights: The European Convention on Human Rights and English Abortion Law', Medical Law Review 24 (2016), 1.

${ }^{64}$ See M. Brazier \& N. Glover, 'Does Medical Law Have a Future?' in D. Hayton (ed) Law's Future(s) (Oxford: Hart, 2000), 371.

${ }^{65}$ S. McGuinness and J. Montgomery, 'Submission to the UK All-Party Parliamentary Group on Population, Development and Reproductive Health on Abortion in the Developing World and the UK' (2017) http://www.appg-popdevrh.org.uk/University\%20of\%20Bristol.pdf (accessed 9 August 2019).

${ }^{66} \mathrm{G}$. Sedgh at al, 'Abortion incidence between 1990 and 2014: global, regional, and subregional levels and trends' Lancet 388 (2016), 258 https://doi.org/10.1016/S0140-6736(16)30380-4 ; S. Singh et al., Abortion Worldwide 2017: Uneven Progress and Unequal Access, (New York: Guttmacher Institute, 2018) available at https://www.guttmacher.org/report/abortion-worldwide-2017 (accessed 9 August 2019).

${ }^{67}$ Greater Glasgow Health Board v Doogan [2014] UKSC 68. See further J. Montgomery, 'Conscientious objection: personal and professional ethics in the public square' Medical Law Review 23(2) (2015), 200 68 Medical Law, 3.
} 
ameliorate risks to health in the population), and of the limitations on the power of the state to constrain for the common good the autonomy, privacy, liberty, proprietary, and other legally protected interests of individuals.... ${ }^{69}$ Here, the criteria are drawn from political theory.

A different sort of claim is made by Hervey and McHale - about legal integrity - when they suggest that 'Health Law may be seen generally, as a composite of principles derivative from other legal disciplines, such as standard principles of criminal law (applicable for instance, in the context of euthanasia and abortion); civil law (applicable in malpractice litigation); and family law. ${ }^{70}$ Thus, there may be no expectation of coherence within the subject area of health law but consistency with wider legal doctrine would be sought. Under such an approach, scholars might need to compare the application of the doctrine of necessity to questions about the value of life across areas such as survival during shipwreck, ${ }^{71}$ terrorist duress, ${ }^{72}$ sterilization, ${ }^{73}$ detention of the incapacitated, ${ }^{74}$ and abortion ${ }^{75}$ rather than consider the issues as being specific to the health context. This implies a different framework of critique than those of scholars who argue that while legal activities might begin by borrowing from wider legal doctrines, principles are 'adapted' so that 'a tentative new and distinct branch of law emerged'. ${ }^{76}$ Once the adaptations have occurred, the underlying unity of the new branch of law, as discussed above, can be identified. This can only really be assessed when the boundaries of the subject matter have been defined. Until then, the branch of law has not become sufficiently distinct to merit analysis.

We can also see differences in the sense of purpose that scholars proclaim. These are not necessarily driven by the different labels, but there is a pattern whereby those who adopt particular names tend to think about the aims of the law in similar ways to each other and different from those who prefer a different description. Thus, it has been said that 'the prime objective of public health law is to pursue the highest possible level of physical and mental health in the population, consistent with the values of social justice. ${ }^{77}$ Medical law seems to aim to ensure the accountability of doctors, ${ }^{78}$ especially through the role of law ${ }^{79}$ and sees Bolamisation as problematic because it shows an abdication of the regulatory mission of law. ${ }^{80}$ Health Care Law often has a concern with the improvement of clinical care and sees Bolamisation as problematic because it prevents the law working to raise standards. ${ }^{81}$

${ }^{69}$ L. Gostin Public Health Law - Power, Duty, Restraint (Berkley, CA: University of California Press, $2^{\text {nd }}$ ed 2008), 4, quoted in Coggon What Makes Health Public?, 87.

${ }^{70}$ T. Hervey \& J. McHale, 'Law, Health and the European Union' Legal Studies 25 (2005), 228, at 231.

${ }^{71} R$ v Dudley and Stephens (1884) 14 QBD 273, A.W.B. Simpson, Cannibalism and the Common Law (Chicago: Chicago University Press, 1984).

72 Lynch v DPP for Northern Ireland [1975] AC 653, R v Howe [1987] 1 All ER 779.

${ }^{73} \mathrm{~F} v$ W Berkshire HA [1989] 2 All ER 545.

${ }^{74} R v$ Bournewood Community and Mental Health NHS Trust, ex $p$ L [1999] 1 AC 458, Cheshire West and Chester Council v $P$ [2014] UKSC 19.

${ }^{75} R$ v Bourne [1939] KB 687.

${ }^{76}$ E. Wicks, Human Rights and Healthcare (Oxford: Hart, 2007), 1.

77 Gostin Public Health Law, 4 quoted in Coggon What Makes Health Public?, 87.

78 I. Kennedy, Unmasking of Medicine (London: George Allen and Unwin, 1981).

${ }^{79}$ C. Foster and J.Miola, "Who's in Charge? The Relationship between Medical Law, Medical Ethics and Medical Morality," Medical Law Review 23(4)4 (2015), 505.

$80 \mathrm{~J}$. Miola, 'Medical Law and Medical Ethics: Complementary or Corrosive?' Medical Law International 6 (2004), 251. See also M. Brazier 'The Age of Deference - A Historical Anomaly' in M. Freeman (ed) Law and Bioethics (Oxford: OUP, 2008) 465.

$81 \mathrm{~J}$ Montgomery, 'The role of law in raising standards of consent' in P. Alderson (ed) Consent to Treatment and Research (London: Institute of Education Social Sciences Research Unit, 1992). 
Two well-known cases might be used as illustrations of these challenges. Gillick ${ }^{82}$ has been variously interpreted as an example of Bolamisation ${ }^{83}$ and of patients' rights. $^{84}$ Montgomery ${ }^{85}$ can be seen as the vindication of consumerist bioethics as per Kennedy, ${ }^{86}$ the codification of good practice, ${ }^{87}$ the promotion of patient-centred value-based practice, ${ }^{88}$ in tension with evidence-based practice, ${ }^{89}$ and as abandoning the shared teleology of the doctor-patient relationship..$^{90}$ These analyses reflect the different understandings of scholars of what the law should be aiming to achieve as much as any variation in interpretation of the legal doctrine established by those decisions. One of the anonymous reviews of this piece asked whether Montgomery was also a question of fundamental human rights. This is difficult to accept on the evidence of the judgments. There are two places at which this is discussed. In the first, discussing Sidaway, ${ }^{91}$ it is suggested that the duty of care placed on doctors was generated by patient's rights but the human rights argument of Lord Scarman was treated as the making same point as the non-human rights version adopted by Lord Templeman. ${ }^{92} \mathrm{At}$ the second point, human rights is one of many examples of a general social movement away from deference to expertise and paternalistic judgments..$^{93}$ There had been an interesting foray into the potential for human rights as a foundation of disclosure in the decision of the Court of Appeal in Tracey $v$ Cambridge University Hospitals NHSFT ${ }^{94}$ but this was not considered by the Supreme Court. ${ }^{95}$ The perception that Montgomery is a human rights case seems to me to be an imposition based on expectations and a desire that we should develop such an approach not a fair reading of the Justices' approach. It reinforces the point that in any discussion of the appropriateness of a name for the subject area, these tendencies to incorporate implicit purposes should be borne in mind.

A final framing concern is raised by the question whether the medical/health context of an issue is key or incidental. The 'right to die' offers a boundary question of this type. ${ }^{96}$ Are we concerned with the right to die on the part of individuals? If so, we might focus on the scope of privacy and whether states are entitled to impose a particular version of the value of life. Perhaps we are more worried about the potential for abuse. If so, the issue might be best discussed with other safeguarding problems (elder or child abuse) or approaches to regulatory oversight (such as licensing and inspection). Perhaps we should examine the general principles that underly crimes against the person and whether they suggest that the conditions for criminal responsibility have been met.

82 Gillick v W Norfolk \& Wisbech AHA [1985] 3 All ER 402.

${ }^{83}$ Miola, Medical Ethics and Medical Law ch 5.

${ }^{84}$ J. Montgomery, 'Children as Property?' Modern Law Review 51 (1988), 323.

${ }^{85}$ Montgomery v Lanarkshire Health Board [2015] UKSC 11.

${ }^{86}$ R. Heywood, 'R.I.P. Sidaway: Patient-Oriented Disclosure - A Standard Worth Waiting For?' Medical Law Review 23 (2015) 455.

${ }^{87}$ A.M. Farrell \& M. Brazier 'Not so new directions in the law of consent? Examining Montgomery $v$ Lanarkshire Health Board' Journal of Medical Ethics 42(2) (2016), 85.

88 J. Herring, K.M.W. Fulford, M. Dunn, \& A. Handa, 'Elbow Room for Best Practice? Montgomery, patients' values, and balanced decision-making in person-centred clinical care' Medical Law Review 25 (2017), 582.

$89 \mathrm{~J}$ Montgomery \& E. Montgomery, 'Montgomery on informed consent: An inexpert decision?' Journal of Medical Ethics 42(2) (2016), 89.

90 J. Montgomery, 'Patient No Longer? What's next in health care law?' Current Legal Problems 70 (2017), 73.

${ }^{91}$ Sidaway v Bethlem RHG [1985] 1 All ER 645.

92 Montgomery paras [43] and [56].

93 [80].

94 [2014] EWCA Civ 822. See further S. Delacroix, "At a cross-roads? The courts' shifting apprehension of the vulnerability at stake in the lay-healthcare provider relationship", Journal of Medical Law and Ethics, (2019).

95 Judgment was given just over a month before the oral arguments before the Supreme Court in Montgomery.

96 J. Coggon, 'Assisted Dying and the Context of Debate: "Medical Law" versus "End-of-life Law'" Medical Law Review 18 (2010), 541. 
These arguments would apply to family and private mercy killings as well as to health care professionals. However, it could be that the key issue thought to concern proper professional standards in medical or physician-assisted suicide? If so, then health care law seems an appropriate context and to make particular regulatory tools available (e.g. loss of professional registration).

Depending on which perspective dominates, different issues come to the fore. Our approach to conscientious exemption is likely to be very different, as discussed earlier in relation to abortion. A focus on privacy rights tends to privilege questions of harms, and their control through safeguards, over arguments about human dignity. The criminal law perspective might concentrate on whether we are concerned with defences (that justify prohibited behaviours as a lesser evil) or excuses (that explain why the actions were not blameworthy) ${ }^{97}$ It might also consider the consistency between the general law of homicide and decisions in the health cases. From this view it can be argued that the standard distinction between motive and intention has been improperly blurred, that causation rules have been lazily applied, and that the 'medical exemption' has been extended beyond its proper remit. ${ }^{98}$ Whether this critique seems powerful will turn in part on whether end of life issues are seen as distinctively within the concerns of medical/health lawyers or rather part of the general law of the land.

A final example concerns capacity law. Should the principles of capacity law be developed from the experience of health provision or the management of property? The Mental Capacity Act 2005 offers a composite and comprehensive legislative approach but previously there were separate statutes and the Law Commission consulted separately on health and property issues. ${ }^{99}$ Some argue that the Hippocratic tradition's emphasis on beneficence has been a source of discrimination and is in tension with Convention on Rights of Persons with Disabilities. ${ }^{100}$ The health perspective has perhaps distorted our understanding of the rights that are at stake and their value. This we have paid considerably more attention to fertility rights than to rights to express sexuality in the litigation and literature around non-consensual sterilisation. Our concern over medicalisation has led to greater concentration on rights of liberty in relation to the 'detention' of the incapacitated than to their rights of association - we stress the controlling aspects of professional care rather than its enabling. ${ }^{101}$ By linking ideas of autonomy with consent rather than opportunity, we may have

\footnotetext{
97 J. Horder, Excusing Crime (Oxford: Oxford University Press, 2004), ch 5 includes discussion of mercy killing.

${ }^{98}$ S. Fovargue \& A. Mullock (eds.), The Legitimacy of Medical Treatment: What Role for the Medical Exception? (London: Routledge, 2016).

${ }^{99}$ The Enduring Powers of Attorney Act 1985 applied only to the management of property. The background to the consolidation in the Mental Capacity Act 2005 was discussed in the Law Commission report Mental Capacity (London: HMSO 1995, LC231), available (along with the consultation documents) at https://www.lawcom.gov.uk/project/mental-incapacity/\#related (accessed 10 August 2019).

100 L Series, 'Relationships, autonomy and legal capacity: Mental capacity and support paradigms' International Journal of Law and Psychiatry 40 2015, 80; L Series \& A. Nilsson, 'Article 12 CRPD: Equal recognition before the law' in I. Bantekas, M.A. Stein \& D. Anastasiou (eds.), The UN Convention on the Rights of Persons with Disabilities: A Commentary (Oxford: Oxford University Press, 2018), 339.

${ }^{101}$ See e.g. the suppression of the importance of L's relationship with his carers in $R v$ Bournewood Community and Mental Health NHS Trust, ex $p$ L [1999] 1 AC 458, and the subsequent challenges of interpreting the legislation on 'Deprivation of Liberty Safeguards', e.g. Cheshire West and Chester Council v P [2014] UKSC 19. The Supreme Court is shortly to given judgment on a case in which the relationship between deprivation of liberty and normal family life for children is a key issue; see Re D (A Child) Case ID: UKSC 2018/0064, heard in October 2018, on appeal from [2017] EWCA Civ 1695. See for earlier explorations the discussion of the potential of rights of association in Re C [1993] 1 FLR 940 and Cambridgeshire CC v R [1995] 1 FLR 50.
} 
delayed the development of legal expectations of the empowerment of patients with impaired capacity. ${ }^{102}$

\section{Labels as Icons}

Up to this point, the discussion of the naming of our subject has considered activities within the domain of legal scholars. However, we should also acknowledge that labels also act as cultural icons for the dynamics of the wider socio-political-historical contexts in which they are situated. ${ }^{103}$ They point us to connections, social meanings and enable us to engage in shared conversations. They remind us that the specific conversations are influenced by the positions that we take on other issues. It may be that when we discuss the appropriateness of a label for legal activities, we would be better advised to think about the background in which the law is operating than the immediate tasks it engages with. Thus, the various 'Medical' labels demonstrate the dominance of doctors in the organisation of labour, ${ }^{104}$ the sense of the need to work out the place of medicine in the social order as old relationships of power and deference become renegotiated. ${ }^{105}$ The connection assumed between medical law and bioethics draws lawyers into processes by which theologians and philosophers have reinvented themselves to keep their influence (and jobs). ${ }^{106}$ As 'Health Care Law' makes little sense unless there is a near-monopoly socialised provider system, then interest is likely to coloured by the degree of sympathy with that approach to health care delivery. The emergence of 'public health law' is linked with a new paradigm for public health; ${ }^{107}$ reflecting the changing patterns of mortality and morbidity, concerns with the persistence of health inequalities, and the recognition that much ill health is socially determined. It means something different when connected with the sanitarian movement than it does when social determinants are the key target. The former perspective is still important in relation to international trade and health hazards, ${ }^{108}$ but the latter would be a distraction in a context that lacks redistributive or collective intent. 'Health law' is not merely a broader concept than medical law, but it also reflects an increasing dominance of market tools; as capitalist health provision moved towards greater social regulation and social insurance systems become more mixed-market economies. ${ }^{109}$ The UK Supreme Court's reshaping of medical and health care law is in part driven by a reconceptualization of what it is to be a patient and in part be a rethinking of the role of professions in society. ${ }^{110}$

The engagement of law with the social organisation of healing is one of the enduring themes that shapes how the law develops, along with our understanding of who and why human embodiment

\footnotetext{
102 M Donnelly, Changing Values and Growing Expectations: The Evolution of Capacity Law' Current Legal Problems 70 (2017), 305.

103 Morgan \& Lee, 'Regulating the Risk Society'.

104 M. Stacey, The Sociology of Health and Healing (London: Unwin Hyman 1988).

105 See e.g. D Kelleher, J Gabe \& G Williams (ed), Challenging Medicine (London: Routledge, $2^{\text {nd }}$ ed 2006); E.

Friedson, Professionalism: The Third Logic (Cambridge: Polity Press, 2001); T. Johnson, Professions and Power

(London: Routledge, 1972).

${ }^{106}$ Rothman, Strangers at the bedside, and Evans, The history and future of bioethics.

107 J Ashton \& H Seymour, The New Public Health (Milton Keynes: Open University Press, 1988).

108 L. Gostin, Global Health Law ch 6.

${ }^{109}$ C.M. Flood \& A. Gross, The Right to Health at the Public-Private Divide: A Global Comparative Study

(Cambridge: CUP 2014).

110 Montgomery, 'Patient no longer?'.
} 
matters, and how we tolerate science and respond to scandal. ${ }^{111}$ Thus, we need to locate legal developments in their contexts. Ian Kennedy's cultural appropriation of USA bioethics has been linked with the 'new public management' and 'Audit Society' movements, and with the agendas of Thatcherism. ${ }^{112}$ We may also be able to 'read' legal events (cases, legislative reform) as indications of cultural values and conflicts within wider society. Derek Morgan and Robert Lee coined the phrase 'stigmata cases' to capture this iconographic element of legal material. ${ }^{113}$ Our labels may obscure these values and conflicts as well as illuminate them, as when the emergence of 'modern medical law' in the 1980s neglected the recent history of engagements in moral questions under the label of the meaning and value of 'life'. ${ }^{114}$

Earlier in the paper the role of naming the subject in professional scholarly careers was discussed. There may also be a significant impact of personal histories too that connect with lives outside the academy. For me personally, the adoption of the label of 'Health Care Law' could be said to be in part an adverse reaction against medical dominance (showing my wife's influence as a nurse and midwife), an affective commitment to the National Health Service (which grew in importance as my public service developed), and a tendency to heresy (the psychological need to be on the edge of and challenging to the status quo, which in turn might be psycho-analysed as a father-son thing). ${ }^{115}$ Appreciating these histories help separate the accidental, contingent, or incidental aspects of the way in which names are chosen in order to assess how far they can be useful independently and how far they makes sense only within their original context. We may need to defer discussion of the most appropriate names until we have considered the way in which services are delivered and how we would like them to be. We may also need to lower expectations and accept that a degree of inconsistency may be inevitable.

\section{Some Imaginaries}

With these caveats in mind, we should sketch out some considerations facing scholars choosing descriptions for their work today. First, the different concerns of usefulness in terms of descriptive and normative dimensions. Those who see their principal role as 'serving' the rule of law faithfully will probably want to ensure their work is descriptively rigorous, even when this is aimed also to provide a foundation for critique. They may be primarily concerned with 'fit' with the current legal materials. ${ }^{116}$ In Kuhnian terms, they will worry if their explanations are full of anomalies, which suggests their paradigm is becoming stretched as a representation of the material being studied. Such an approach privileges the importance of explanatory power in relation to existing materials but will have a secondary aim of predictive power in relation to future judicial decisions or legislative interventions. It will also be likely to base critique on ideas such as consistency and coherence. As

\footnotetext{
111 Brazier \& Montgomery, 'Whence and Whither'

112 Wilson, 'Who Guards the Guardians?'.

${ }^{113}$ D. Morgan \& R. Lee, 'Regulating the Risk Society'.

${ }^{114}$ See the discussion in Brazier \& Montgomery, 'Whence and Whither' at 18 on the neglect of e.g. G. Williams The Sanctity of Life and the Criminal Law (1958), N St John-Stevas Life, Death and the Law (1961).

${ }^{115}$ E Owusu-Dapaa (2016) An Inquiry into the Emergence of Health Care Law in England and Wales as a Distinct Body of Law - What Lessons Can be Drawn From this in Relation to Ghana? University of Lancaster PhD Thesis, at $\mathrm{p} 228$ observes as a second motivation for my approach the ' $\mathrm{HCL}$-related questions that he had to answer from his partner who was training as a nurse at the time' (I am now her husband and she a midwifery academic). These personal drivers may be more common than one might imagine. He also notes that Peter Skegg's interest was also nurtured by a girlfriend who was training as a nurse, and whom he married, see $p$ 226.

${ }^{116}$ See R Dworkin, Law's Empire (London: Fontana, 1986) for a discussion of 'fit' in relation to legal interpretation.
} 
discussed earlier, these criteria require some sort of delineation of the boundaries of a subject in order to tell whether apparent divergences threaten internal coherence (and require change) or suggest that the material belongs in a different subject area (and so can be excluded from consideration without abandoning the paradigm). In general, this concern with fit will be a useful approach if we anticipate continuity between the contemporary position and the future. It is less attractive if we dislike the foundations of the current law, or if we see a period of disruption ahead of us. ${ }^{117}$

Those looking for change need to address a different set of concerns, essentially about political and conceptual desirability. These may be driven by aims to provide a comprehensive account of the role of law in social life or human well-being. There are also significant challenges in demonstrating political legitimacy, ${ }^{118}$ especially in areas relation to life and death that are highly controversial within societies but generally assumed to be within the remit of our subject area. ${ }^{119}$ For those tempted to preserve ethics in the future label, it will be therefore be necessary to justify the law endorsing substantive ethical content on matters that are contested. In the 1950s and 1960s this was described as a problem of the enforcement of morals. Now it seems that staples of the medical law and ethics paradigm such as abortion and euthanasia are under pressure. Why should the law support one rather another side in the culture wars over the nature of respect for life? Dworkin's analysis of the USA experience of abortion and euthanasia, suggests that medical law and ethics has catalysed deep cultural divisions, politicised the courts, and poisoned the rule of law. ${ }^{120}$ The House of Lords in Purdy and the UK Supreme Court in Nicklinson has flirted with activism of a sort that needs careful justification. ${ }^{121}$ The turn to human rights as a basis for distinguishing democratic and judicial competences will be a crucial test for the future of this imaginary.

For those whose focus is health services, a way needs to be found to give shape to a deliberately fragmented provider system so that analysis is possible. It is no longer obvious how the boundaries of regulatory activity should be defined. From an English perspective at least, social care now looks to be integral, not peripheral, to the system whose legal constitution cannot easily described because it has become so complex. While I am not persuaded that privatisation is a helpful reference frame, ${ }^{122}$ the multiplicity of public, not-for-profit and commercial organisations seems here to stay. You cannot explain the regulation of abortion services without engaging with the status of non-NHS providers as they provide most of the terminations that the NHS funds in England. ${ }^{123}$ In the age of internet services, there may be no need to involve health professionals at all, something

\footnotetext{
117 J Masson, 'Disruptive Judgments' (2017) 29 CFLQ 401-22.

118 Montgomery, 'The Legitimacy of Medical Law'.

119 J. Montgomery, 'Bioethics as a Governance Practice' Health Care Analysis 24(1) (2016), 3.

${ }^{120}$ R Dworkin, Life's Dominion (London: Random House, 1993). For discussion of the transfer of USA tactics to the UK, see S McGuinness, 'A guerilla strategy for a pro-life England' Law Innovation and Technology 7(2) (2015), 283.

${ }^{121}$ Purdy v DPP [2009] UKHL 45, R (Nicklinson) v Min Justice; $R$ (AM) v The Director of Public Prosecutions [2014] UKSC 38; J. Finnis, 'Invoking the Principle of Legality against the Rule of Law' New Zealand Law Review (2010), 601, J. Finnis, 'Judicial Power: Past, Present and Future' (2015), available at http://judicialpowerproject.org.uk/wp-content/uploads/2015/10/John-Finnis-lecture-20102015.pdf (accessed 10 August 2019); Lord Sumption 'Human Rights and Wrongs', the third of the Reith Lectures 2019, transcript at http://downloads.bbc.co.uk/radio4/reith2019/Reith_2019 Sumption lecture 3.pdf (accessed 10 August 2019).

${ }^{122}$ A. Pollock, NHS PIc: The Privatisation of Our Health Care (London: Verso, $3^{\text {rd }}$ ed 2009).

${ }^{123}$ Abortion Statistics, England and Wales: 2018 (London: Department of Health and Social Care, 2019), 10, Fig. 3.
} 
that may even require the reallocation of abortion to a different area of law. ${ }^{124}$ Similarly, as those involved in innovation come from outside the traditional health professions, the regulation of health research can no longer assume that those carrying out the research have any understanding of or commitment to the tradition of health research ethics that we trace through from Nuremberg through the Declaration of Helsinki. ${ }^{125}$ There is a proliferation of engineering solutions, digital initiatives, citizen science, direct-to-consumer products. Nor can we assume that the public supports the precautionary approach to regulation that developed to deal with drug relation, strengthened by the exposure of the damage caused by Thalidomide. A desire for untested 'innovation', a lack of trust in traditional expertise, and overconfidence in the hyped up promises that are made by those promoting products suggest that the professional and institutional gatekeeping that has made health care law manageable is unlikely to continue. ${ }^{126}$ We should anticipate a very different world ahead as we imagine the approach that legal scholars might adopt.

Health Law provides an easier basis for international comparison because of its breadth, although this may be misleading as it is far from clear that it is used in the same way in different jurisdictions. My sense is that it probably needs to determine whether its centre of gravity lives in markets or the health focus. As we imagine the future of our scholarship as fundamentally a descriptive project, then we should be concerned primarily with market entry conditions (licences to practise individually and as organisations), limits to market activities (e.g. proscribed actions), quality regulation, and the distributive justice requirements when the market fails and people are harmed. If we imagine our health law project as normative, then we might begin with the right to health, ${ }^{127}$ and consider the institutions of global health governance. ${ }^{128}$ To do this with integrity, we should be prepared to question the roles of law and especially the courts and maintain a degree of scepticism as to whether law is a progressive or regressive force.

We have seen that when the selection of titles is approached knowingly, it becomes an assertion of power; sometimes in order to exert control, but also in resistance. As such, we need to be able justify our exercise of power (or failure to engage with power). This will need to include consideration of our primary audiences: are we aiming to influence people in the clinic or in court? This seems an important element of the different approaches of lan Kennedy and Margot Brazier. ${ }^{129}$

\footnotetext{
${ }^{124}$ S Sheldon, 'How Can a State Control Swallowing? The Home Use of Abortion Pills in Ireland' Reproductive Health Matters 24 (2018), 90-101.

125 This may explain some of the problems that the Royal Free and Google Deep Mind ran into, not least when their legal advisers lacked experience of the health research context. Their project concerned the integration of datasets held by the hospital to enable risks of acute kidney injury to be predicted. The Information Commissioner was not satisfied that there was adequate disclosure to patients to comply with data protection law and required the Trust to undertake an audit (https://ico.org.uk/about-the-ico/news-and-events/newsand-blogs/2017/07/royal-free-google-deepmind-trial-failed-to-comply-with-data-protection-law/\#) The audit report from Linklaters LLP saw professional guidance as of limited relevance, see 63-65, available at https://www.royalfree.nhs.uk/news-media/news/royal-free-london-publishes-audit-into-streams-app/. For the Information Commissioner's response, reserving its position on some of the legal interpretation, see (https://ico.org.uk/about-the-ico/news-and-events/news-and-blogs/2018/06/statement-in-response-topublication-of-the-royal-free-audit-report/). All links accessed 21 August 2019.

${ }^{126}$ D. Meyerson, 'Medical Negligence Determinations, the "Right to Try," and Expanded Access to ITs' Journal of Bioethical Inquiry 14(3) (2017), 385; J. Miola, 'Bye-bye Bolitho? The curious case of the Medical Innovation Bill' Medical Law International 15(2) (2015) https://doi.org/10.1177/0968533215605667.

${ }^{127}$ A. Krajewska, 'Bioethics and Human Rights in the Constitutional Formation of Global Health' Laws 4(4) (2015), 771; doi:10.3390/laws4040771.

${ }^{128}$ C. Clinton \& D. Sridhar Governing Global Health: who runs the world and why? (Oxford: OUP 2017).

129 J Montgomery, 'The Compleat Lawyer - Medical Law as Practical Reasoning: Doctrine, Empiricism, and Engagement' Medical Law Review 20 (2012), 9.
} 
Which are the relevant professional audiences? The content of my textbook on Health Care Law was determined by the questions I got asked by health professionals, meaning that some sections were closely related to legal activity (e.g. consent to treatment), others by reference to practical problems (confidentiality and data protection - leading to a realisation of the importance of professional and NHS guidance in giving practical advice) and others by the need to make a realistic prediction of what courts might do (such as in relation consent to research where there were no UK cases). Perhaps each audience requires a label of its own.

This leads to a final thought; that it may be that we should not take the challenges of identifying an ideal label too seriously. Legal scholars have been able to make significant contributions in health care, the regulation of novel technologies, and public bioethics without needing to resolve their differences in relation to the best description of their subject. Thus, major public service roles have been undertaken by academics working in the field despite their differences over naming the subject. These including chairing public inquiries, policy consultations, statutory regulators, key nongovernment organisations such as Nuffield Council on Bioethics. There are plenty of things to think about in relation to the process of naming, but perhaps the journey of reflection matters more than the destination. Perhaps the most fundamental value of medical, health care, or health lawyers lies in being rigorous legal scholars, with open minds and ready to acknowledge their limitations, rather than in the marking out of their territory in any specific way. ${ }^{130}$

${ }^{130}$ See J. Montgomery, 'The Fundamental Value(s) of Health Lawyers' paper to the Society of Legal Scholars Medical Law Subject Section September 2018, draft available on request from the author. 